\title{
The Antidiabetic and Anti-microbial Activity Analyses in The Extract of Methanol, Ethyl Acetate, and Hexane from Flesh of Matoa (Pometia pinnata J. R. Forst. \& G. Forst)
}

\author{
Henny Rochaeni ${ }^{1}$, Candra Irawan ${ }^{1}$, Hanafi $^{2}$, Poppy Sri Lestari ${ }^{3, *}$, \\ Lilis Sulistiawaty ${ }^{1}$ and Ima Lia Dwi Putri ${ }^{2}$ \\ ${ }^{1}$ Department of Chemical Analysis, Politeknik AKA Bogor, Bogor 16154, Indonesia \\ ${ }^{2}$ Department of Food Industrial Quality Assurance, Politeknik AKA Bogor, Bogor 16154, Indonesia \\ ${ }^{3}$ Department of Industrial Waste Treatment, Politeknik AKA Bogor, Bogor 16154, Indonesia
}

('Corresponding Author’s Email: poppy.srilestari@gmail.com)

Received: 24 July 2020, Revised: 25 May 2021, Accepted: 31 May 2021

\begin{abstract}
The current research was designed to examine the antidiabetic and anti-microbial activities in the extracts of methanol, ethyl acetate and hexane from Flesh of Matoa (Pometia pinnata J. R. Forst. \& G. Forst) to find out the best solvent to produce antidiabetic and anti-microbial active compounds. In the phytochemical screening, hexane extracted alkaloids and terpenoids, while ethyl acetate extracted saponin and methanol extracted tannin, phenol and terpenoids. In the antidiabetic activity by $\alpha$-glucosidase inhibition methods, ethyl acetate showed the highest percentage of inhibition and the smallest value of $\mathrm{IC}_{50}$, followed by hexane and methanol compared to the Quercetin as the control group. The maximum percentage inhibition was $36.74 \pm 0.07$ for $100 \mu \mathrm{g} / \mathrm{mL}$ of concentration. The minimum value of $\mathrm{IC}_{50} \mathrm{was}$ observed at $159.74 \pm 0.65 \mu \mathrm{g} / \mathrm{ml}$ compared to the control group $6.04 \pm 0.14 \mu \mathrm{g} / \mathrm{ml}$. The smaller the $\mathrm{IC}_{50}$ value, the stronger the antidiabetic activity. Anti-microbial inhibition activities assessed using antimicrobial diffusion test method. The hexane and ethyl acetate extracts provide an inhibition of fungi and bacteria compared to Ketoconazole and Amoxicillin as the standard. The maximum fungi inhibition zone was observed at $4 \mathrm{~mm}$ for $A$. flavus and $9 \mathrm{~mm}$ for $A$. niger by Hexane extracts compared to the standard 14 and $24 \mathrm{~mm}$. The maximum bacteria inhibition zone was observed at $7 \mathrm{~mm}$ for $B$. cereus by both of hexane and ethyl acetate extracts compared to the standard $5 \mathrm{~mm}$. Compared to the anti-microbe inhibitory power categories, hexane and ethyl acetate was on the range of weak and moderate. The methanol extract could not inhibit all types of microbe. This study concluded that various extract of flesh of Matoa showed antidiabetic and anti-microbial activities at different value with varying potencies. The ethyl acetate extract was found to be more potent among all, followed by hexane and methanol.
\end{abstract}

Keywords: Methanol, Ethyl acetate, Hexane, $\mathrm{IC}_{50}$ value, Phytochemical screening, Antidiabetic, Antimicrobial, Matoa

\section{Introduction}

Indonesia has mega-diversity of natural resources. One of the most important biodiversity is of medicinal plants and one of which is Matoa originating from Papua, Indonesia. This plant has the Latin name Pometia pinnata J. R. Forst. \& G. Forst [1]. Matoa grows from lowlands to highlands, from the beach to the mountains and from wet soil to dry soil. Matoa trees include perennials. The tree can grow large with an average height of 18 meters with an average maximum diameter of $100 \mathrm{~cm} \mathrm{[2].}$

The application of plants as a source of medicine has been increasing [3]. People use the extracts from several types of medicinal plants to treat diabetes in a traditional way [4]. The application of plant extracts as antidiabetic drugs has been widely investigated by inhibiting an $\alpha$ - enzyme activity glucosidase in a bitter melon fruit [5], loquat [6], and Satawari [7]. Some types of plant extract substances from phenolic groups and alkaloids have $\alpha$-glucosidase inhibitory activity, so they can be used as antidiabetic. Those results consistent with research that states flavonoids, alkaloids, terpenoids, anthocyanins, glycosides, and phenolic compounds possess significant inhibitory activity against $\alpha$ - 
glucosidase enzyme [8]. Another method that had been used for reducing blood glucose was reducing glucose absorption through inhibition of carbohydrate enzymes such as $\alpha$-amylase [9], so that it was expected to control the increase of postprandial blood glucose [10]. The result of Photochemical Screening of Various Plants and their activity are given in Table $\mathbf{1 .}$

Table 1 Phytochemical Screening of Various Plants and Their Activity.

\begin{tabular}{|c|c|c|c|c|}
\hline No. & Plants & Active compound & Activity & References \\
\hline 1. & $\begin{array}{l}\text { Momordica } \\
\text { charantia var. charantia and } M \text {. } \\
\text { charantia var. muricata (Bitter } \\
\text { Melon }\end{array}$ & $\begin{array}{l}\text { Alkaloids. Flavonoids, Phenols, } \\
\text { and Terpenoids }\end{array}$ & Antidiabetic & {$[5]$} \\
\hline 2. & Eriobotrya japonica (Loquat) & $\begin{array}{l}\text { Phenols, Flavonoids, Tannin, } \\
\text { Saponins, Alkaloids, Proteins, } \\
\text { Carbohydrates, Glycosides, and } \\
\text { Steroids }\end{array}$ & Antidiabetic & {$[6]$} \\
\hline 3. & $\begin{array}{l}\text { Asparagus racemosus Willd } \\
\text { (Satawari) }\end{array}$ & $\begin{array}{l}\text { Flavonoids, Tannins, Phenolic, } \\
\text { Saponins, Amino acids, and } \\
\text { Protein }\end{array}$ & Antidiabetic & {$[7]$} \\
\hline 4. & $\begin{array}{l}\text { Garcinia } \\
\text { mangostana (Guttiferae). } \\
\text { Nenhelium lannaceum L. } \\
\text { (Sanindaceae). Barringtonia } \\
\text { racemosa (Lecvthidaceae), } P \text {. } \\
\text { acidus (gooseberrv). C. } \\
\text { cauliflora (namnam). M. } \\
\text { fragrans (nutmeg). C. } \\
\text { caudatus (Ulam Raia). O. } \\
\text { stamineus (Misai Kucing) }\end{array}$ & $\begin{array}{l}\text { Flavonoids. Alkaloids. } \\
\text { Ternenoids. Anthocvanins, } \\
\text { Glycosides, and Phenolic }\end{array}$ & Antidiabetic & [8] \\
\hline 5. & Senna surattensis (EESS) & $\begin{array}{l}\text { Steroids, Triterpenoids, } \\
\text { and Flavonoids }\end{array}$ & Antidiabetic & [9] \\
\hline 6. & $\begin{array}{l}\text { Archidendron bubalinum (Jack) } \\
\text { I.C Nielsen (Julang-jaling) }\end{array}$ & $\begin{array}{l}\text { Alkaloids, Flavonoids, Tannins, } \\
\text { Phenols, Saponins Terpenoids }\end{array}$ & $\begin{array}{l}\text { Anti- } \\
\text { Microbial }\end{array}$ & [13] \\
\hline
\end{tabular}

Phytochemical compounds had been studied and known to have health benefits. The alkaloid compounds were reported as the chemical compounds that could prevent disease and some derivatives of alkaloids exhibit biological activities such as anti-inflammatory [11], anti-malarial [12], and antimicrobial [13]. In addition, saponins are used as anti-microbials in recent years. The mechanism of action of saponins as anti-bacterial is to reduce surface tension resulting in increased permeability or leakage of cells resulting discharge of intracellular compounds [14]. Terpenoids was anti-bacterial [15].

The active compounds produced by the matoa plant have been tested for their efficiency. Previous research had been conducted on Matoa bark with ethanol extract contained flavonoids, tannins, terpenoids and saponins which had antidiabetic activity [16]. Methanol extract of Matoa seeds also had antidiabetic activity with $\mathrm{IC}_{50}$ of $169.81 \mu \mathrm{g} / \mathrm{mL}$ [17]. Matoa leaves could be used as an anti-oxidant and anti-microbial agent [18]. Anti-microbial tests on the rind of Matoa had been carried out using plate and liquid diffusion tests. The results showed that the highest anti-microbial activity had been produced by acetone extract with the value of $\mathrm{IC}_{50}$ was $15.32 \mathrm{ppm}$ with extract of ethanol was $143.23 \mathrm{ppm}$ and $451.31 \mathrm{ppm}$ [19]. Based on previous research, the efficiency of flesh of Matoa as an antidiabetic and anti-microbial agent has not been studied yet and further development was needed.

The current research was designed to examine the antidiabetic and anti-microbial activities in the extracts of methanol, ethyl acetate and hexane from Flesh of Matoa (Pometia pinnata J. R. Forst. \& G. Forst) to find out the best solvent to produce antidiabetic and anti-microbial active compounds. The 
research expected that the flesh of Matoa had the potential as a cure for diabetes. Due to the variety of bioactive compounds contained in plant materials and their differing solubility properties in different solvents, the optimal solvent for extraction depends on the particular plant materials, and the compounds that are to be isolated [11]. The three solvents were selected by having different polarity properties. The hexane was non-polar, ethyl acetate was semi-polar and methanol was polar. They were widely used as the solvents to obtained active compounds of plants such as Asparagus racemosus Willd [7] and Phaleria macrocarpa [20]. Moreover, the three solvents are considered cheaper and safer compared to other solvents.

\section{Materials and methods}

The research method consisted of the following stages. First of all, the extraction of flesh of Matoa fruit using methanol, ethyl acetate, and hexane; and then phytochemical screening extract of flesh of Matoa fruit consisting of flavonoid, tannin, phenol, saponin, terpenoids and alkaloid compound screening; antidiabetic activity test using $\alpha$-glucosidase enzyme, and anti-microbial diffusion test method consisting of anti-bacterial and anti-fungal using each of 2 types of bacteria and 2 types of fungi.

\section{The extraction of Flesh of Matoa}

The matoa fruit was peeled, then separated from the outer rind. The flesh of Matoa was washed, drained (Figure 1(a)) and dried (Figure 1(b)) in a direct sunlight for $4 \mathrm{~h}$. The flesh of Matoa simplicial (50 grams) were extracted with 1:10 (b/v) solvent. The solvents were methanol, ethyl acetate and nhexane. The extraction had been done in $2 \times 24 \mathrm{~h}$ by maceration (Figure 1(c)). The results of maceration were filtered, then evaporated with a rotary evaporator at $50{ }^{\circ} \mathrm{C}$.

\section{The Alkaloids examination}

About $100 \mathrm{mg}$ of solvent extracts of flesh of Matoa was mixed in $5 \mathrm{~mL}$ of a $10 \%$ hydrochloric acid, then $\mathrm{pH}$ was adjusted to $\mathrm{pH} 8$ by diluting with ammonia solution. The mixture was added with $20 \mathrm{~mL}$ chloroform and then dried. The extracts were tested with Dragendorf reagent and Mayer's reagent. The formation of white precipitate of Mayer reagent and red precipitate of Dragendorf reagent indicated the presence of alkaloids [21].

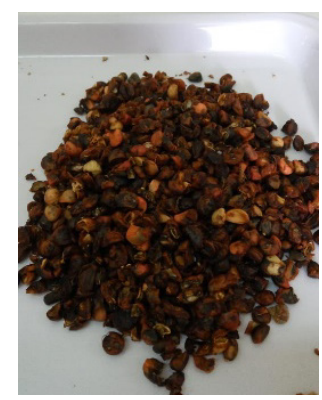

(a)

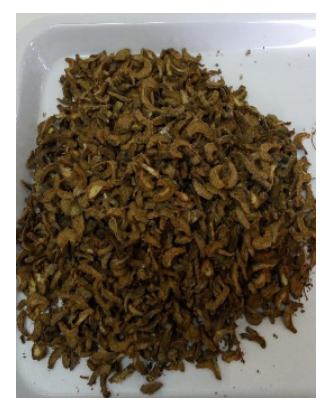

(b)

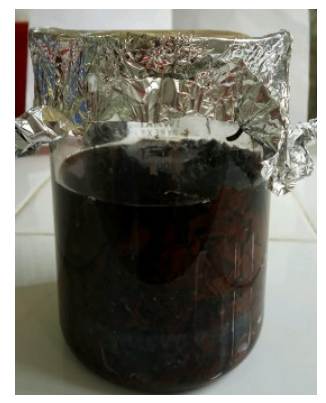

(c)

Figure 1 The extraction of Flesh of Matoa, (a) Drained, (b) Dried, and (c) Maceration.

\section{The flavonoids examination}

About $100 \mathrm{mg}$ of the solvent extracts of flesh of Matoa dissolved in $100 \mathrm{~mL}$ of hot water, and then boiled for $5 \mathrm{~min}$ and filtered. Furthermore, $5 \mathrm{~mL}$ of the filtrate was mixed with $0.1 \mathrm{mg}$ of magnesium powder, $1 \mathrm{~mL}$ of the concentrated hydrochloric acid and $1 \mathrm{~mL}$ of the amyl alcohol. Then, they had been shaken vigorously. The color would be changed to yellow or red or orange that indicated the presence of flavonoid [21].

\section{The terpenoids and steroids examination}

About $100 \mathrm{mg}$ of solvent extracts of flesh of Matoa had been mixed with $25 \mathrm{~mL}$ diethyl ether and shaken. The diethyl ether layer had been separated then added by 2 - 3 drops of Lieberman-Burchard reagents. The bluish color of the interface indicated the positive results for the presence of the terpenoids while greenish color indicated the positive results for the presence of the steroids [21]. 


\section{The saponins examination}

About $100 \mathrm{mg}$ of solvent extracts of flesh of Matoa had been added to $10 \mathrm{~mL}$ of boiled distilled water, and then cooled and shaken vigorously for $10 \mathrm{~min}$. The foam formation was observed and became stable with the addition of 1 drop of $2 \mathrm{~N}$ hydrochloric acid that indicated the presence of the saponins.

\section{The Tannins and Polyphenols Examination}

About $100 \mathrm{mg}$ of methanol extracts were extracted with $1 \mathrm{~mL}$ ethanol and $1 \mathrm{~mL}$ distilled water. The filtrate was mixed with a few drops of $1 \% \mathrm{FeCl}_{3}$ and another filtrate had been added with gelatin salt. Then, the changing color of the green or blue or purple color indicated the presence of the tannins.

\section{The $\alpha$-Glucosidase inhibition test}

About $250 \mu \mathrm{L}$ solution of p-nitrophenyl- $\alpha$-D-glucopyranoside of $5 \mathrm{mM}$ and $495 \mu$ l phosphate buffer $0.1 \mathrm{M}$ at $\mathrm{pH} 7$ was added to the reaction tube containing $5 \mu \mathrm{L}$ of the sample solution in DMSO with concentrations variation of $100,50,25$, and $10 \mu \mathrm{g} / \mathrm{mL}$. After the solution was homogeneous, the solution would be pre incubated for $5 \mathrm{~min}$ at $37{ }^{\circ} \mathrm{C}$. The reaction was initiated by the addition of $250 \mu \mathrm{L} \alpha$ glucosidase solution ( 0.062 units) and the incubation lasted for $15 \mathrm{~min}$. The reaction stopped by the addition of $1 \mathrm{~mL}$ of $\mathrm{Na}_{2} \mathrm{CO}_{3} 0.2 \mathrm{M}$. The activity of the enzyme was measured based on the reading of pnitrophenol absorbance at $\lambda 400 \mathrm{~nm}$. Quercetin had been used as a reference standard with concentration of $10,7.5,5,2.5$, and $1 \mu \mathrm{g} / \mathrm{mL}$. The $\%$ inhibition was measured by using the equation:

$\%$ inhibition $=\frac{(B-S)}{B} \times 100$

$\mathrm{B}=$ Absorbance of blank (DMSO)

$\mathrm{S}=$ Absorbance of sample

\section{The anti-microbial activity test}

The petri dishes contained a nutrient agar medium added about $200 \mu \mathrm{L}$ of suspension of one of the test bacteria (E. coli and B. cereus). For the anti-fungal test, the media used was Potato Dextrose Agar (PDA) for testing the A. plavus and A. niger. Afterward, it had been prepared a sterile tracing paper pieces (discs $6 \mathrm{~mm}$ in diameter) to be placed on the surface of the agar on the petri dish. The disc was previously immersed in a test solution for $30 \mathrm{~min}$ in a sterile petri dish. Then, the incubation process had been carried out at $37{ }^{\circ} \mathrm{C}$ for $24 \mathrm{~h}$. The observations were made by measuring the zone of resistance that had been formed around the disc paper in the form of a clear area using a ruler and then recorded. The inhibit zone was measured by using the equation:

Inhibit Zone $=$ Diameter $($ clear area + discs $)-$ Diameter paper disc

\section{Results and discussion}

\section{Phytochemical screening}

Phytochemical screening was an initial test that had been carried out to examine the components or chemical compounds contained in a natural ingredient. This screening had been carried out qualitatively using several types of tests and reagents. The phytochemical screening consisted of alkaloid, flavonoids, tannins, phenols, saponins and terpenoids in the flesh of Matoa extracts had been carried out using three different solvents, which were hexane, ethyl acetate and methanol. The three solvents had different polarity properties. The hexane was non-polar, ethyl acetate was semi-polar and methanol was polar. The results of the flesh of Matoa fruit phytochemical screening are given in Table 2. 
Table 2 Phytochemical Screening of Flesh of Matoa Extract in the Various Solvents.

\begin{tabular}{lccc}
\hline Types of screening & Hexane & Ethyl acetate & Methanol \\
\hline Alkaloids: & & & - \\
Meyer & + & - & - \\
Dragendorf & + & - & \\
& & & - \\
Flavonoid & - & - & + \\
Tannin & - & - & + \\
Phenol & - & - & - \\
Saponin & - & + & + \\
Terpenoid & - & - & + \\
\hline
\end{tabular}

The hexane extract of flesh of Matoa resulted the alkaloid and terpenoid compounds, while the ethyl acetate resulted the saponin compounds. The content of tannins, phenols and terpenoids in flesh of Matoa recovered by using the methanol solvents. The screening results showed that all extracts did not contained flavonoids and methanol solvents could extract more variation of chemical compounds than hexane and ethyl acetate solvents. The number of types of chemical compounds extracted were in accordance with the level of polarity of compounds that were contained in the natural materials. Figure 2 showed the phytochemical screening of Hexane, Methanol and Ethyl Acetate Extract of Flesh of Matoa.

Figure 2 Phytochemical screening of Hexane, Methanol and Ethyl Acetate Extract of Flesh of Matoa.

The phytochemical screening of flesh of Matoa extract had a result that it contained active compounds, one of which could be an anti-microbial. The anti-microbial test had been carried out using the anti-microbial diffusion test method to determine the anti-microbial activity of flesh of Matoa extract. The anti-microbial activity test had been carried out on 2 types of bacteria (E. coli and Bacillus cereus) and 2 types of fungi (Aspergillus flavus and Aspergillus niger), namely by measuring the amount of inhibitory power referring to the clear zone size formed around the disc. The results of the anti-microbial test on flesh of Matoa fruit extract can be seen in Table 3. 
Table 3 Inhibitory Power of Anti-microbial of Flesh of Matoa Extract.

\begin{tabular}{|c|c|c|c|c|}
\hline \multirow{2}{*}{$\begin{array}{l}\text { Types of } \\
\text { microbe }\end{array}$} & \multicolumn{4}{|c|}{ Microbe inhibition zone (mm) } \\
\hline & Hexane & Ethyl acetate & Methanol & Standard \\
\hline \multicolumn{4}{|c|}{ Fungi } & Ketoconazole \\
\hline A. niger & 4 & 2 & - & 14 \\
\hline A. flavus & 9 & 6 & - & 24 \\
\hline \multicolumn{4}{|c|}{ Bacteria } & Amoxicillin \\
\hline E. coli & - & - & - & 5 \\
\hline B. cereus & 7 & 7 & - & 5 \\
\hline
\end{tabular}

Description: sign (-) = no clear zone

The anti-microbial categories were divided into weak $(<5 \mathrm{~mm})$, medium $(5-10 \mathrm{~mm})$, strong $(10$ $20 \mathrm{~mm}$ ) and very strong $(>20 \mathrm{~mm})$ [22]. The hexane and ethyl acetate extract could inhibit A. flavus and $A$. niger and $B$. cereus bacteria with a weak to moderate inhibition $(2-9 \mathrm{~mm})$, while the methanol extract of flesh of Matoa fruit could not inhibit all types of microbial test. The inhibitory power of hexane and ethyl acetate extract of flesh of Matoa on the growth of $A$. flavus and $A$. niger fungi showed a lower value than the standard ketoconazole antifungal $(14-24 \mathrm{~mm})$, but the inhibitory power of gram-positive $B$. cereus bacteria was higher than the anti-bacterial standard of amoxicillin inhibitory power ( $5 \mathrm{~mm}$ ).

The hexane extract of flesh of Matoa has had more anti-microbial than in the ethyl acetate extract. This was happened in accordance with the results of the phytochemical screening in Table 3 which showed the presence of alkaloid compounds that were more dominant than in the ethyl acetate extracts. The alkaloids had become alkaline when met the nitrogen atoms and could inhibit the microbial growth by inhibiting cell wall synthesis, changing membrane permeability and inhibiting protein synthesis [23]. In addition, the presence of the terpenoid compounds which were anti-bacterial and anti-fungal could inhibit A. flavus, A. niger and B. cereus.

All the extracts of flesh of Matoa could not inhibit the growth of gram-negative bacteria (E. coli). In contrast to gram $(+)$ bacteria that had $60-80 \%$ peptidoglycan, gram (-) bacteria and fungi had complex cell walls that was the outer layer of cell walls with liposaccharide composition, lipoprotein and periplasm bound peptide [24]. Lipoprotein with Porin type had a hydrophilic characteristic and could not interact with anti-bacterial compounds that were hydrophobic. That could make it more difficult to inhibit gramnegative bacteria.

\section{The results of flesh of matoa fruit inhibition against diabetes}

The graphic that connected the concentration of methanol to the \% inhibition data produced a standard curve equation $\mathrm{y}=0.0679 \mathrm{x}+6.6221$ with a value of $\mathrm{R}^{2}=0.7995$ (Figure 3(a)). While the standard curve for ethyl acetate and hexane solvents were $y=0.2492 x+10.227$ with the value $R^{2}=0.9324$ and $y=0.0985 x$ +9.2647 with the value $\mathrm{R}^{2}=0.9218$ (Figures 3(b) and $\mathbf{3}(\mathbf{c})$ ). The $\mathrm{IC}_{50}$ value calculated from the obtained value of the intercept and the slope of each solvent. The results of the inhibition of flesh of Matoa fruit with various solvents at concentrations of 10, 25, 50, and $100(\mu \mathrm{g} / \mathrm{mL})$ and $\mathrm{IC}_{50}$ values are given in the Table 4. The $\alpha$-glucosidase breaks down the disaccharides into simpler sugars, readily available for the intestinal absorption. The inhibition of their activity, in the digestive tract of humans, is considered to be effective to control diabetes by diminishing the absorption of glucose decomposed from starch by these enzymes [25].

The ethyl acetate showed the highest percentage of inhibition and the smallest value of $\mathrm{IC}_{50}$, followed by hexane and methanol compared to the Quercetin as the control group. The maximum percentage inhibition was $36.74 \pm 0.07$ for $100 \mu \mathrm{g} / \mathrm{mL}$ of concentration. The minimum value of $\mathrm{IC}_{50} \mathrm{Was}$ observed at $159.74 \pm 0.65 \mu \mathrm{g} / \mathrm{mL}$ compared to the control group $6.04 \pm 0.14 \mu \mathrm{g} / \mathrm{mL}$. The $\mathrm{IC}_{50}$ value was inversely proportional to its antidiabetic activity. The smaller the $\mathrm{IC}_{50}$ value, the stronger the antidiabetic activity. This also showed that the efficiency of using ethyl acetate was better than other solvents. If it was associated with the phytochemical screening results of ethyl acetate (Table 1), it had been known that ethyl acetate solvents could extract the saponin compounds. The saponin compounds, according to the research results, were known to inhibit $\alpha$-glucosidase activity [26]. Saponins inhibit the work of enzymes $\alpha$-glucosidase i.e. enzymes in the intestines that served to change carbohydrates into glucose. Enzyme $\alpha$-glucosidase inhibited the absorption of glucose in the intestines, so that it served as the antihyperglycemic. The effect of saponins on the composition of cell membranes were inhibit the molecules 
absorption and caused disruption to glucose transporter system caused its obstacle the glucose absorption [20].

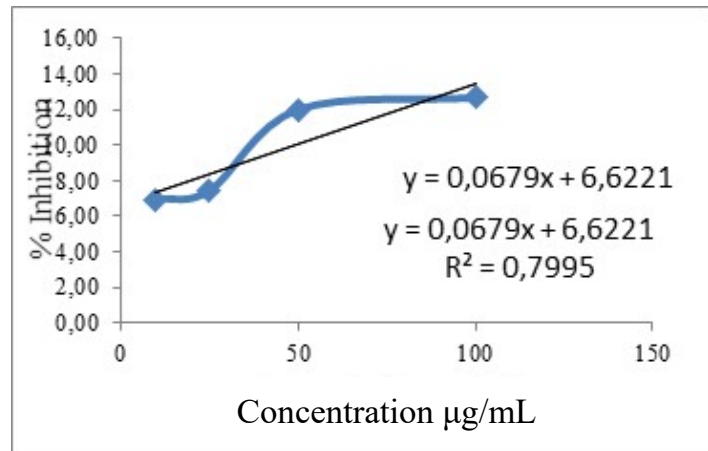

(a)

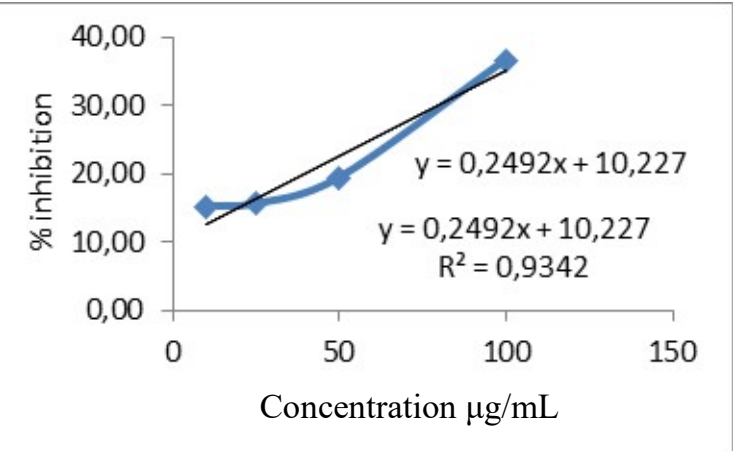

(b)

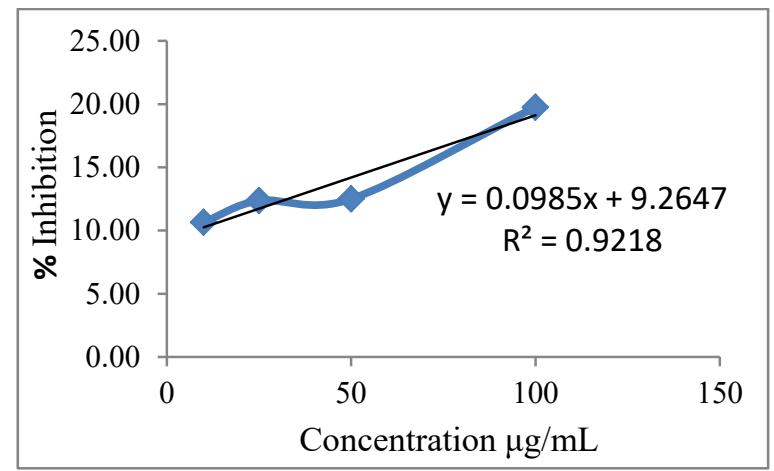

(c)

Figure 3 Inhibition Percentage of Methanol (a), Ethyl Acetate (b) and Hexane (c).

Table 4 Inhibition Results and $\mathrm{IC}_{50}$ of Flesh of Matoa Extracts from Different Types of Solvents and Concentration Variations.

\begin{tabular}{lccc}
\hline Standard/Sample name & Concentration $(\boldsymbol{\mu g} / \mathbf{m L})$ & \% Inhibition & $\mathbf{I C}_{\mathbf{5 0}}(\boldsymbol{\mu g} / \mathbf{m L})$ \\
\hline Quercetin & 1 & $7.42 \pm 0.85$ & $6.04 \pm 0.14$ \\
& 2.5 & $27.01 \pm 3.23$ & \\
& 5 & $45.22 \pm 1.33$ & \\
Methanol Extract & 7.5 & $61.06 \pm 0.31$ & \\
& 10 & $77.59 \pm 1.10$ & $341.93 \pm 5.02$ \\
Ethyl Acetate Extract & 10 & $6.94 \pm 0.06$ & \\
& 25 & $7.43 \pm 0.01$ & \\
& 50 & $12.00 \pm 0.03$ & \\
& 100 & $12.68 \pm 0.01$ & \\
Hexane Extract & 10 & $15.25 \pm 0.04$ & \\
& 25 & $15.60 \pm 0.05$ & \\
& 50 & $19.41 \pm 0.03$ & $207.32 \pm 1.97$ \\
\hline
\end{tabular}


The $\mathrm{IC}_{50}$ of hexane extract was at $207.32 \pm 1.97 \mu \mathrm{g} / \mathrm{mL}$. The hexane extracted the alkaloid and terpenoid compounds. The terpenoids and saponins have the same anti-hyperglycemic activity that helped the glucose uptake in muscles and inhibited glucose uptake in the digestive tract and insulin release activity [27]. The alkaloids had the expediency as the antidiabetic [28]. The alkaloid and terpenoid extracted using the hexane solvent could act as an antidiabetic inhibitor of the $\alpha$-glucosidase enzyme.

The methanol extract gave the highest $\mathrm{IC}_{50}$ value that was at $341.93 \pm 5.02 \mu \mathrm{g} / \mathrm{mL}$. The phytochemical screening gave qualitative data. Even though the methanol extracted tannin, phenol and terpenoids compound from flesh of Matoa, but the quantity data was not available. The highest percentage of inhibition by methanol extract was $12.68 \pm 0.01$ for $100 \mu \mathrm{g} / \mathrm{mL}$ concentration. It was the same amount with hexane extract for $25 \mu \mathrm{g} / \mathrm{mL}$ concentration. The methanol ineffectively inhibited the $\alpha$ glucosidase enzyme.

\section{Conclusions}

The hexane extracted alkaloids and terpenoids, while ethyl acetate extracted saponin and methanol extracted tannin, phenol and terpenoids. The phytochemical screening showed that the flesh of Matoa had the potential as a cure for diabetes. The ethyl acetate showed the highest percentage of inhibition and the smallest value of $\mathrm{IC}_{50}$, followed by hexane and methanol compared to the Quercetin as the control group. The maximum percentage inhibition was $36.74 \pm 0.07$ for $100 \mu \mathrm{g} / \mathrm{mL}$ of concentration. The minimum value of $\mathrm{IC}_{50}$ was observed at $159.74 \pm 0.65 \mu \mathrm{g} / \mathrm{mL}$ compared to the control group $6.04 \pm 0.14 \mu \mathrm{g} / \mathrm{mL}$. The hexane and ethyl acetate extracts provided an inhibition of fungi and bacteria compared to Ketoconazole and Amoxicillin as the standard. Compared to the anti-microbe inhibitory power categories, hexane and ethyl acetate was on the range of weak and moderate. The methanol extract could not inhibit all types of microbe. This study concluded that various extract of flesh of Matoa (Pometia pinnata J. R. Forst. \& G. Forst) showed antidiabetic and anti-microbial activities at different value with varying potencies. The ethyl acetate extract was found to be more potent among all, followed by hexane and methanol.

\section{Acknowledgments}

The authors would like to acknowledge Politeknik AKA Bogor under Ministry of Industry of Indonesia for providing laboratory facility and financial fund support.

\section{References}

[1] Rahmawaty, JB Samosir, R Batubara and A Rauf. Diversity and distribution of medicinal plants in The Universitas Sumatera Utara Arboretum of Deli Serdang, North Sumatera, Indonesia. Biodiversitas 2019; 20, 1457-65.

[2] IM Leiwakabessy and BO Paga. Technology test for making sirup Matoa (Pometia pinnata) in household scale. Median J. 2018; 10, 1-8.

[3] Y Asyawati. 2013, Uji Inhibisi terhadap Enzim $\alpha$-glukosidase dan Identifikasi Senyawa Bioaktif dari Ekstrak Buah Bligo (Benincasa hipsida) serta Aktivitas Antioksidannya. Ph. D. Dissertation. University of Indonesia, Depok, Indonesia.

[4] M Bahmani, H Golshahi, K Saki, MR Kopaei, B Delfan and T Mohammadi. Medicinal plants and secondary metabolites for diabetes mellitus control. Asian Pac. J. Trop. Dis. 2014; 4, 687-92.

[5] ST Assefa, EY Yang, SY Chae, M Song, J Lee, MC Cho and S Jang. Alpha glucosidase inhibitory activities of plants with focus on common vegetables. Plants 2020; 9, 2.

[6] L Mogole, W Omwoyo and F Mtunzi. Phytochemical screening, anti-oxidant activity and $\alpha$-amylase inhibition study using different extracts of loquat (Eriobotrya japonica) leaves. Heliyon 2020; 6, e04736.

[7] R Vadivelan, RG Krishnan and R Kannan. Antidiabetic potential of Asparagus racemosus willd leaf extracts through inhibitions of $\alpha$-amylase and $\alpha$-glucosidase. J. Tradit. Complement. Med. 2019; 9, 1-4.

[8] DAM Bukhari, MJ Siddiqui, SH Shamsudin, MM Rahman and SZM So'ad. $\alpha$-Glucosidase inhibitory activity of selected malaysian plants. J. Pharm. Bioallied. Sci. 2017; 9, 164-70.

[9] E Thilagam, B Parimaladevi, C Kumarappan and SC Mandal. $\alpha$-Glucosidase and $\alpha$-amylase inhibitory activity of senna surattensis. J. Acupunct. Meridian. Stud. 2012; 6, 24-30.

[10] Agarwal and Prashant. Alpha-amylase inhibition can treat diabetes mellitus. Res. Rev. J. Med. Health Sci. 2016; 5, 1-8. 
[11] DH Truong, DH Nguyen, NTA Ta, AV Bui, TH Do and HC Nguyen. Evaluation of the use of different solvents for phytochemical constituents, antioxidants, and in vitro anti-inflammatory activities of Severinia buxifolia. J. Food Qual. 2019; 2019, 8178294.

[12] VK Dua, V Gaurav, S Bikram, R Aswathy, B Upma, DA Dau, NC Gupta, K Sandeep and R Ayushi. Anti-malarial property of steroidal alkaloid conessine isolated from the bark of Holarrhena antidysebterica. Malar. J. 2013; 12, 1-6.

[13] C Irawan, Foliatini, Hanafi, L Sulistiawaty and M Sukiman. Volatile compound analysis using GCMS, phytochemical screening and antioxidant activities of the Husk of "Julang-Jaling" (Archidendron bubalinum (Jack) I.C Nielsen) from Lampung, Indonesia. Pharmacogn. Mag. 2018; 10, 92-8.

[14] SE Nugraha, S Achmad and E Sitompul. Antibacterial activity of ethyl acetate fraction of passion fruit peel (Passiflora edulis Sims) on Staphylococcus Aureus and Escherichia Coli. Indones. J. Pharm. Clin. Res. 2019; 2, 7-12.

[15] AC Guimarães, LM Meireles, MF Lemos, MCC Guimarães, DC Endringer, M Fronza and R Scherer. Antibacterial activity of terpenes and terpenoids present in essential oils. Molecules 2019; 24, 2471.

[16] SP Mataputun, JA Rorong and J Pontoh. Aktivitas inhibitor $\alpha$-glukosidase ekstrak kulit batang Matoa (Pometia pinnata spp.) sebagai agen antihiperglikemik. Jurnal MIPA UNSRAT. 2013; 2, 119123.

[17] M Sukiman', JA Margaretha, C Irawan, Hanafi and L Sulistiawaty. Evaluation of antidiabetes activity of Matoa seed extract (pometia pinnata) using enzym $\alpha$-glucosidase. J. Pharm. Innov. 2018; 7, 10-12.

[18] Kuspradini, WF Pasedan and IWD Kusuma. Aktivitas antioksidan dan antibakteri ekstrak daun Matoa (Pometia pinnata). Jurnal Jamu Indonesia 2016; 1, 26-34.

[19] Faustina, Fransisca, C Santoso, dan Filiana. Ekstraksi Dan Pengamatan Aktivitas Antioksidan Dan Antimikroba Dari Kulit Buah Pometia Pinnata. Jurnal Pascapanen Pertanian 2014; 11, 80-8.

[20] HO Edeoga, DE Okwu and BO Mbaebre. phytochemical constituent of some nigerian medicinal plants. J. Biotechnol. 2005; 4, 685-8.

[21] N Fiana, D Oktaria. Pengaruh kandungan saponin dalam daging buah mahkota dewa (Phaleria macrocarpa) terhadap penurunan kadar glukosa darah. Major. J. 2016; 5, 128-32.

[22] WS Rita. Isolasi, identifikasi dan uji aktivitas antibakteri senyawa golongan triterpenoid pada rimpang temu putih. Jurnal Kimia 2010; 4, 20-6.

[23] Mangunwardoyo. Antimicrobial and identification of active compound curcuma xanthorizaRoxb. Int. J. Basic Appl. Sci. 2012; 12, 69-78.

[24] WA Volk and MF Wheeler. Mikrobiologi Dasar (Terjemahan), Jilid 2. Erlangga, Jakarta, 1991.

[25] VB Nguyen, QV Nguyen, AD Nguyen and SL Wang. Screening and evaluation of glucosidase inhibitors from indigenous medicinal plants in Dak Lak Province. Vietnam Res. Chem. Intermed. 2016; 43, 1-17.

[26] Y Denga, H Kai, Y Xiaoli, C Xin, H Jing, L Xuegang, Y Lujiang, J Yalan, J Qing and L Panpan. Saponin rich fractions from Polygonatu modoratum (Mill.) druce with more potential hypoglycemic effects. J. Ethnopharmacol. 2012; 141, 228-33.

[27] E Fisman, M Motro and A Tenenbaum. Non-insulin antidiabetic therapy in cardiac patients: Current problems and future prospects. Adv. Cardiol. 2008; 45, 154-70.

[28] E Ferrannini and A Solini. SGLT2 inhibition in diabetes mellitus: Rationale and clinical prospects. Nat. Rev. Endocrinol. 2012; 8, 495-502. 